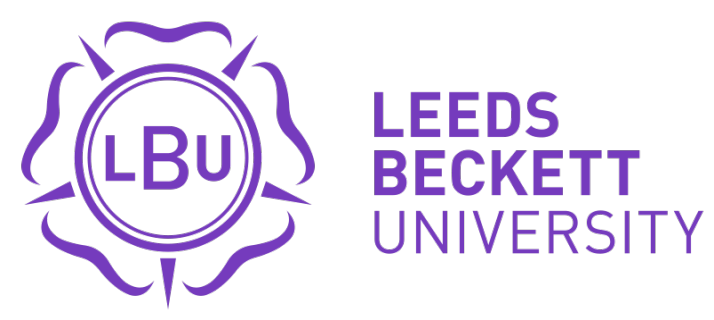

Citation:

Wood, S and Gardiner, S (2019) Policing UK Airports and Schedule 7 of the Terrorism Act 2000: The Young Passengers' Perception of Security Measures. Terrorism and Political Violence. ISSN 0954-6553 DOI: https://doi.org/10.1080/09546553.2019.1638255

Link to Leeds Beckett Repository record:

https://eprints.leedsbeckett.ac.uk/id/eprint/6135/

Document Version:

Article (Accepted Version)

The aim of the Leeds Beckett Repository is to provide open access to our research, as required by funder policies and permitted by publishers and copyright law.

The Leeds Beckett repository holds a wide range of publications, each of which has been checked for copyright and the relevant embargo period has been applied by the Research Services team.

We operate on a standard take-down policy. If you are the author or publisher of an output and you would like it removed from the repository, please contact us and we will investigate on a case-by-case basis.

Each thesis in the repository has been cleared where necessary by the author for third party copyright. If you would like a thesis to be removed from the repository or believe there is an issue with copyright, please contact us on openaccess@leedsbeckett.ac.uk and we will investigate on a case-by-case basis. 


\title{
Policing UK Airports and Schedule 7 of the Terrorism Act 2000: the young passengers' perception of security measures.
}

\begin{abstract}
Policing airports following $9 / 11$ has been challenging with an emphasis on visibility and high levels of security checks for passengers. The focus has been on a form of 'reassurance policing' and an emphasis on procedural justice which is accepted as legitimate on the part of the public. However, there have been claims that Muslim passengers are under greater suspicion than other passengers and have been subject to the practice of 'racial profiling'. The powers under the Terrorism Act 2000, notably Schedule 7 have been under scrutiny as to the extent that they allow the police to stop and search suspects. This study reviews the opinions and experiences of young passengers at UK airports to see if they are reassured by policing and their opinions on profiling fellow passengers.
\end{abstract}

Keywords: Terrorism, reassurance policing, procedural justice; profiling, aviation, passenger experience, security

\section{Introduction}

Since the events of $11^{\text {th }}$ September 2001 (9/11), the visibility of policing has increased at UK airports in response to the perceived and actual threat of terrorism. Passengers are subject to more prolonged security checks. The visibility of patrolling police with firearms, police vehicles parked off-road and near roundabouts and of police stations at large airports, has it is argued, served as a reassurance to passengers and a deterrent to terrorists. These developments in so-called 'reassurance policing', ${ }^{1}$ have concurrently given legitimacy to exert greater police powers to this perceived risk. ${ }^{2}$ Additionally the security procedure that 
passengers are subject to is increasingly demanding. Airport security concerning embarkation is twofold; the first phase is the electronic screening of passengers by metal detectors which can result in a pat-down by security if metal is detected or full-body scanning followed by a pat-down. The second process is the potential of passengers being profiled stopped and screened by the police. When disembarking, passengers are subject to immigration checks and possible police checks. In both cases of these security checks, Schedule 7 of the Terrorism Act 2000 (TA 2000) is the legal instrument in the UK to determine whether the passenger is a potential or actual terrorist.

Fundamental flaws in airport terminal security were highlighted with two nail bombing attacks in March 2016 at Brussels Airport in Zaventem (a third attack took place during this period at Maelbeek Metro station in Brussels). In these attacks, 31 victims and three suicide bombers were killed and 300 people were injured. ${ }^{3}$ These attacks exposed how easy it was to enter an airport departure area and detonate explosives. Although the rationale for high visibility of policing is to prevent repeat offences of this nature and fortify public confidence and that of business, ${ }^{4}$ a major question is whether reassurance policing can really be a deterrent to committed terrorists. $^{5}$

The profiling of air passengers for stopping, questioning and a possible search has been employed since the introduction of security to prevent terrorist attacks on passenger flights in the 1970 s, ${ }^{6}$ with profiling for potential hijackers and terrorists first occurring at Israeli airports. ${ }^{7}$ Passenger behaviours, such as undertaking odd travel patterns, looking nervous, avoiding eye contact, sweating, displaying unusual behaviour, carrying suspicious documents, and the giving of unconvincing answers to reasonable questions are all worthy of further investigation. ${ }^{8}$ However in general terms, before the events of $9 / 11$ in New York, aviation security, investigation and possible intervention had focussed predominately on illegal activities such as contraband rather than terrorism. ${ }^{9}$

Since 9/11, terrorist attacks and attempts on aviation in the west, have been carried out, predominately, but not exclusively, by male Muslims aged 18-35..$^{10}$ Studies both in the United 
Kingdom $^{11}$ and in the United States ${ }^{12}$, have identified significant levels of concern within Muslim communities that they are being targeted at airports for additional searches and questioning. Ethnic or Racial profiling of this type in the U.S. and most western democracies has attracted considerable criticism as being immoral and likely to be unconstitutional and illegal. ${ }^{13}$ Airport security has impacted on ethnic minority travellers, particularly young male Muslims, who suggest they are treated as 'others' under a greater suspicion, primarily due to the media representation of the stereotypical radical and extremist terrorist. ${ }^{14}$

The main argument put forward in support of racial profiling is a pragmatic one: since 9/11 terrorists have been overwhelmingly young Muslim men, this group therefore should be targeted. ${ }^{15}$ However, the counter-argument is that the ineffectiveness of racial profiling does not justify its use and ferments malcontent within relevant communities and promotes radicalisation of individuals. ${ }^{16}$ The reality is that the main reason for passengers being stopped and questioned at airports is not due to the application of a racial profiling, but the more mundane factor that an individual's hand luggage has triggered an alarm and warrants further investigation. Airport security since $9 / 11$ has resulted in additional time needed to screen passengers in a sector that has dramatically increased in the numbers of air travellers.

The current study addresses young passenger perceptions and reassurance of UK airport security and their opinions of profiling passengers for stop and search by utilizing an attitude survey conducted among 711 university students from 2012-2015. One rational for using university students is that since $9 / 11$ a large number of UK university students have either carried out terrorist attacks or supported such causes. However, given that security personal would be unlikely to know passenger status until stopped, the main rational was that these respondents were young passengers, who in this study were between $18-25$. The aim of this study was to review the respondents' views as to profiling passengers from different ethnic categories and the overall reassurance and support for airport security. The data supports the legitimacy of a high level of security to reassure passengers of safety. However, when considering passenger perceptions of airport screening, particularly profiling, in the minority of 
passengers who disagreed with profiling there was a significant difference between the views of white passengers and non-white passengers. This outcome of this study does not suggest the current legitimacy of UK airport security and regulatory framework is in need of wholesale change. One key proposal however is that procedural justice and legitimacy of the security process is embedded into the training of UK security officers to minimise passengers' negative perceptions. Additionally, when measuring this study against the Civil Aviation Authority (CAA) data, young passengers do take longer to process through UK airport security and this study offers a reason why that might be the case.

This article will firstly outline the regulatory framework that is applicable to the security screening at UK airports. This includes an examination of the legal provisions under Schedule 7 of the Terrorism Act 2000, which empowers the police and security officials to stop and search individuals due to security concerns. Secondly, it will be argued that this framework is primarily about reassurance policing or policing by consent. Thirdly, previous studies that have attempted to measure suspect communities and their encounters with authority that suggests the use and practice of racial profiling, will be examined. Fourthly, the findings of the current study of University students as to their attitudes towards the profiling of passengers will be presented. Lastly, the article will suggest reforms to aviation security and the legal framework that empowers police officers to question passengers either as a result of electronic screening or subject to Schedule 7 to determine whether the passenger is a terrorist.

\section{Schedule 7 Terrorism Act 2000: Policing and Security at airports}

Schedule 7 of the TA 2000 applies to ports, which include both seaports and airports. The examining officer can be either a constable, immigration officer, or a customs officer designated by the Secretary of State. ${ }^{17}$ The examining officer can detain a passenger for a maximum of 6 hours for questioning ${ }^{18}$ and detain property for up to 7 days to help determine whether the passenger is a terrorist. ${ }^{19}$ However, unlike the requirements for stopping 
suspected criminals in a public place, there is no need for the examining officer to have reasonable suspicion or grounds for believing the passenger is a terrorist at the point the passenger is stopped. ${ }^{20}$ Parliament has set the bar for the exercise of Schedule 7 powers quite low. ${ }^{21}$ Passengers who wilfully fail to comply or obstruct the examining officer can be liable for up to three-months imprisonment on summary conviction. ${ }^{22}$ Passengers travelling to and from the UK and Ireland can be asked to provide further information; this is known as 'carding'. ${ }^{23}$ Passengers who are examined for more than one hour, but not detained, will be issued with a 'TACT 1 notice', essentially meaning a receipt of the examination.

Once detained, either because the suspect is non-co-operative, wants to leave during prescreening or the examining officer believes its necessary to detain the suspect, further detention is subject to the requirements of Schedule 8 TA 2000. The suspect will be given a notice of detention form called 'TACT 2'. Schedule 8 can require the suspect to undergo a number of checks, for example, finger prints, intimate and non-intimate samples to determine the identification of the passenger. ${ }^{24}$ Schedule 14 of the TA 2000 requires a code of practice to be issued to examining officers who use Schedule 7. The Code for Examining Officers was first published in $2009 .{ }^{25}$ It outlined who should perform Schedule 7 stops, giving preference to police officers, save in exceptional circumstances. Selecting persons for screening should be based on the current threat of terrorism or informed considerations and not solely based on perceived ethnic background or religion. No official profiling programme exists to target ethnicity to prevent terrorism at airports or elsewhere. The 2009 and 2014 Codes of Practice relating to the implementation of Schedule 7 clearly state that no one should be stopped and searched solely on the grounds of ethnicity. ${ }^{26}$

There have been concerns over the extent of the powers under Schedule 7 . In 2011, the former Independent Reviewer of Terrorism Legislation (2011-2017), David Anderson, ${ }^{27}$ suggested the provision was too intrusive and commented in his annual report, 'I believe that a cautious rebalancing could be achieved without materially increasing the risk from terrorism. ${ }^{28}$ This concern over the extensive powers under Schedule 7, together with 
comments from the previous Independent Reviewer (2001-2011) Lord Carlile, are likely to have contributed to a public consultation to review the operation of Schedule 7 in September 2012. ${ }^{29}$ The main response to this consultation was the publication of the 2014 Code of Practice (2014 Code). This development was in the context of new legislation, namely the Anti-Social Behaviour, Crime and Policing Act 2014 (ASBCPA) that amended Schedule 7. One important change was that officers operating Schedule 7 must undergo training on the 2014 Code. The 2014 Code has set out the procedure for stopping suspects, screening and, if necessary, detention for further examination. The 2014 Code concentrated on developing good practice, rather than legal requirements, to try and establish better safeguards and enhanced confidence for both the public and suspects in the process of screening by introducing some accountability for officers carrying out Schedule 7 stops. ${ }^{30}$ Consequently, in his 2015 report, Anderson appeared reassured and was minded to state that the statistics concerning Schedule 7 do not indicate it is being exercised in a discriminatory way. ${ }^{31}$

Although the 2014 Code does not allow ethnicity to be the only reason for stopping someone, once stopped, a person can be questioned about their religious beliefs and activities within their religious community. The relatively high number of persons stopped from certain ethnic backgrounds is evidence to suggest that the 2014 Code will be challenged to provide a fair system and application of Schedule $7 .^{32}$ Lord Kerr dissenting in Beghal v DPP clearly identifies that Schedule 7 is not only likely to do so, but will discriminate against Muslims. This view has not been shared by the majority of judges who have reviewed the use of Schedule 7. However, these concerns have clearly had an impact on Schedule 7 since they have been highlighted by the reduction in its use. In Anderson's 2015 report, the statistics show that the use of Schedule 7 is decreasing. ${ }^{33}$

The use of Schedule 7 is not without limits. An illustration is the case of David Miranda, who was detained at Heathrow airport in 2013 for carrying files related to information contained on social networking servers and phone records of millions of U.S. customers obtained by the whistleblower, Edward Snowden. On appeal the decision was that Schedule 7, as in force at 
the time of this incident, did not provide sufficient protection against the examination of journalistic material. Lord Dyson stated the stop power, if used in respect of journalistic information or material, is incompatible with article 10 [freedom of expression] of the European Convention on Human Rights because it is not 'prescribed by law'. ${ }^{34}$ However, David Miranda's examination by police under Schedule 7 was lawful and proportionate.

Miranda revealed the extent of a new depth of surveillance by the US National Security Agency (NSA) and The Government Communications Headquarters (GCHQ) and the same time provided publicity to Schedule 7 with concerns from some politicians as to how journalists were being treated. ${ }^{35}$ These factors are likely to ensure greater care from and responsibility for chief constables to ensure their officers who carry out their duties under Schedule 7 are acting within the parameters of the 2014 Code.

The changes to Schedule 7 are intended to provide passengers with additional safeguards whilst at the same time setting out clear procedures for designated officers. The legislative changes ${ }^{36}$ and the 2014 Code is designed to achieve this. ${ }^{37}$ Compulsory training for the use of Schedule 7 has become a mandatory requirement for designated officers. It will be difficult to assess the success of the training for designated officers' use of Schedule 7, given reasonable suspicion to stop and screen passengers or make records for the first hour is not required. Designated officers will still have significant powers at ports and airports to stop and screen passengers for up to one hour without having to explaining to the passenger why she/he is being stopped. ${ }^{38}$ This may continue to produce a protracted and steady stream of complaints and accusations of racism from passengers who suffer both professional and unprofessional behaviours that cannot be monitored. Lowe states that the Schedule 7 powers are only used when necessary and should not be portrayed as the norm in how the state and the judiciary deviate in the application of terrorism related powers. ${ }^{39}$

\section{Reassurance Policing}


These moderating changes to Schedule 7 can be seen as an element of 'reassurance policing'. This, according to Innes, has now become a strategy adopted by many police forces where the strategy focuses on police visibility, targeting public order or low level theft offences or as Innes terms, 'signal crimes'. ${ }^{40}$ Whilst these assertions are founded on policing in community neighbourhoods with the support of neighbourhood watch schemes and community officers, they nevertheless can usefully be applied to actions in UK airports to counter terrorist attacks. This policing strategy has its origins in the notions of 'policing by consent', an historical and fundamental philosophical approach of British policing, with its roots in the 'Nine Principles of Policing' from the early nineteenth Century. ${ }^{41}$ One of these principles promotes the need:

\section{'to recognise always that the power of the police to fulfil their functions and duties is dependent on public approval of their existence, actions and behaviour and on their ability to secure and maintain public respect'. ${ }^{42}$}

In terms of airport security in the UK, this manifest itself in terms of a bifurcated approach with the formal security process familiar to users of airports and the specific legal regime that empowers the police to intervene in certain circumstances, augmented with a visible presence of armed police officers. This has been justified on the basis of signalling a strong physical presence and reassurance to the public they are safe and acting as a deterrent to potential terrorist activity. ${ }^{43}$ The display of officers with firearms at airports is commensurate with the National Reassurance Policing Project, which claims that officers who appear visible, in this case with firearms, can give a degree of re-assurance to the public. ${ }^{44}$ The U.S. went further in the aftermath of $9 / 11$ by employing armed air marshals on flights. These officers would remain undercover, but passengers were informed of their presence. ${ }^{45}$

This significantly increased visibility of security can be seen as largely symbolic and intended to re-assure the public. The legitimacy of the security officials and the police at airports draws upon procedural justice theory and psychological responses of the public to regulatory regimes. Within policing studies, this theory necessitates that perceptions of legitimacy on the 
part of citizens' subject to such regimes requires two components, firstly, effectiveness of police conduct and secondly, the engagement of the police with the public. As Brouwer et al argue:

Experiencing fair treatment by the police is the strongest predictor of police legitimacy ... procedural justice is usually seen to incorporate the fairness of the decisions made by officers and the quality of treatment during an interaction. ${ }^{46}$

Simon however argues that $9 / 11$ facilitated the adaptation of increased security processes in the search for effective strategies for terrorist prevention and exploited insecurities of passengers that challenges the reality of confidence in procedural justice. ${ }^{47}$ Together with legislative developments, traction has been given to airport operators and the police to implement a risk assessment programme at a higher level than might be necessary. This has facilitated the justification for targeting of individuals from specific racial and ethnic backgrounds seen as a particular threat and the trust in procedural justice on the part of certain members of these communities having broken down.

\section{Profiling a suspect community}

The security regime at airports is characterised by two opposing explanatory models. The first approach is based on consent, procedural justice and providing security for all travelling through ports. The second is based on identifying risk on pre-determined characteristics of individuals and targeting by way of profiling that characteristic. There is a distinct tension between these two practices. Parallels from policing the terrorist threat in both Northern Ireland and post $9 / 11$ on the UK mainland can be drawn because of the similar sectarian characteristics of these conflicts. ${ }^{48}$ Hillyard in his 1993 study of Irish communities during the Troubles suggested that counter-terrorism policies had created mistrust towards the police and army. ${ }^{49}$ The danger of lumping communities into a broad category of a potential terrorist threat because they may express the mildest concerns about government policy can result in castigating everyone in that community, consequently losing the goodwill of many within it. ${ }^{50}$ 
Chakraborti suggests generalising about the beliefs existing within communities can itself be misleading without understating the diversity of backgrounds within that community. ${ }^{51}$ Counter-terrorism strategies, if poorly applied, can increase the terrorist threat rather than counter it by propagating more support from minorities in those communities. ${ }^{52}$ Pantazis and Pemberton suggest that it can even prolong conflicts. ${ }^{53}$

There have been a number of studies that have focused on UK airport security and the use of Schedule 7 and its effects on minorities, particularly Muslims. A study by Hurrell analysed the use of Schedule 7 from 2010 to 2013 to determine whether it is applied more frequently to ethnic minorities. ${ }^{54}$ She found;

The experimental analysis of race disproportionality suggests that both black and Asian or other ethnic groups experienced high race disproportionality in 2010/11, which was higher for examinations at airports than for those at all ports. Overall, race disproportionality was high for total examinations, higher for over the hour examinations and highest for detentions. ${ }^{55}$

Although there has been a large reduction in recorded Schedule 7 stops since 2010, Hurrell identifies that ethnic groups are still more likely to be stopped using Schedule 7 than white British passengers. ${ }^{56}$

Langley has reviewed the passenger experience of policing and Schedule 7 by contrasting two approaches. The first, the procedural justice model, based on legitimacy of the actions. The second, the experienced utility model associated with 'happy endings', the positive influence that this emotion can have on memories of experiences. ${ }^{57}$ This model is essentially Kahnerman's twist on Jeremey Bentham's concept of utility. Kahnerman suggests two key foundations of experienced utility; 'moment utility' which refers to the experienced utility of an episode in real time and 'remembered utility' which relates to retrospective "global evaluations" of previous incidents in life. In these instances, pleasure and pain can be measured or as Kahnerman suggests they are 'peak and end' moments in which experience can be 
assessed. ${ }^{58}$ Langley found that passengers who had been stopped by security responded more positively to the procedural justice model that treated passengers with dignity and deemed legitimate.

Choudhury and Fenwick reviewed Schedule 7's impact as well as other terrorist legislation on the Muslim community. ${ }^{59}$ They found that the way in which terrorism legislation was being applied affected more negatively on non-white respondents. Additionally, Blackwell and others carried out individual and group interviews with 38 Scottish Muslims concerning their encounters with authority, especially at British airports. ${ }^{60}$ This project did not review Schedule 7 specifically but found that relationships between minorities and the police have often been difficult, which has resulted in creating mistrust between the Muslim community and authority bodies, particularly the police. Their findings found negative encounters at airports with the authorities based on their respondents' perception of being Muslim.

All of these studies raise issues of policing ethnic minorities at airports, particularly the apparent negative effects on the Muslim community and their willingness to cooperate and negative attitudes to being questioned by security. Research in other jurisdictions support these findings including one focusing on the experiences of passengers at an airport in Tel Aviv. As distinct to the U.K., a formal policy of racial profiling is in place. Responses to a series of questions provided that Israeli Arab passengers (overwhelmingly Muslim) compared with Israeli Jewish passengers, had significantly higher levels of agreement that they were treated differently, felt humiliated, and felt intimidated. ${ }^{61}$ In an additional study of 1970 passengers at the Ben-Gurion airport in Israel, Perry and Hasisi suggested ethnic minorities are perceived as posing a potential threat to homeland security, often referred to as "suspect communities." Passengers from suspect communities are subject to rigorous screening, but are also regarded as a source of information, making their cooperation even more important than that of other passengers. The project suggested that passengers belonging to the suspect community of Israeli Muslims were less willing to cooperate with security procedures than all other passengers. However, when controlling for passengers' perceptions of 
legitimacy and procedural justice, Israeli Muslims were more willing to cooperate with airport security than Israeli Jews. ${ }^{62}$

It is useful to also briefly review profiling at U.S. airports because it was the first western country to try to establish a programme to profile for potential terrorists' post $9 / 11$. In October 2003, the U.S. Transport Security Association (TSA) piloted in three airports, a programme called Screening of Passengers by Observations Techniques (SPOT) carried out by Behaviour Detection Officers (BDO). ${ }^{63}$ The U.S. Government Accountability Office's (GAO) report suggested that SPOT, was carried out without any scientific basis, and questioned the programme's reliability. ${ }^{64}$ The TSA responded by identifying that no other programme of this nature had ever been scientifically assessed prior to implementation. ${ }^{65}$ The GAO acknowledged the difficulties in measuring the success of such a programme because profiling passengers is not based on science but on the judgements of individual security staff, which can at times be unreliable and create inconsistencies. Nevertheless, despite concerns, in 2007 the programme was implemented in 42 airports, employing 644 BDO officers. By 2012, the programme had increased staffing to more than 2,800 at 142 airports. ${ }^{66}$ No terrorist has been caught at an airport because of the SPOT programme, despite 199 arrests for other crimes. ${ }^{67}$ In 2013, the SPOT programme was reviewed as lacking a clear strategic plan to identify priorities and establish clear outcomes, by which time costs had increased to $\$ 878$ million. ${ }^{68}$ A report sent to the GAO recommended that future funding for the SPOT programme needed to be limited. ${ }^{69}$ The training of officers for the programme, particularly the refresher courses, were identified as ineffective, ${ }^{70}$ questioning the professionalism of officers in stopping passengers and running a real risk of ethnic profiling. The conclusion is that a programme which had grown out of 9/11 for very good reasons has more than a decade later become dysfunctional and lacking in purpose.

This examination of studies which suggest a practice of racial profiling at airports, is within the context that there is a significant body of evidence to establish that racial profiling by the police both in the U.S. and U.K. has been in existence before $9 / 11,{ }^{71}$ and is clearly not limited to 
airports or ports. ${ }^{72}$ It is a symptom of wider societal issues. Pre 9/11 research in the U.S. had shown that the media had helped to construct and conflate the interconnected racial stereotypes and social realities of crime and justice with images of crime and race. AfroAmerican males have been aligned to crime and consequently influencing police presumptions of culpability. ${ }^{73}$ Similarly in the U.K., acts of terrorism in recent years have seen the media focus on the Muslim community. A useful comparison has been made between the recent targeting of young Muslim males and that of young Catholic males during the 'Troubles' in Northern Ireland. Both the Irish Catholic and Muslim communities have been labelled as suspect and worthy of greater attention. ${ }^{74}$ In addition and interconnected is the process of stereotyping with 'institutional racism' within police organisations identified. ${ }^{75}$ This was a main conclusion of the 1999 Macpherson Report concerning the murder of Stephen Lawrence and the role of the Metropolitan Police. ${ }^{76}$

Canter suggests offender profiling is generally known as the derivation of inferences about a criminal from aspects of the crime(s). ${ }^{77}$ Therefore, identifying passengers at airports as suspected terrorists can only be described as a 'type' of profiling because of the limited information that security officials have on any individual. Welch submits that the perceptions about the presumed racial identity of criminals may be so ingrained in the public consciousness that race does not even need to be mentioned for a connection to be made. ${ }^{78}$ Media reporting about many types of crime and terrorist attacks has become synonymous with race. $^{79}$ It is important to reiterate that racial or ethnic profiling in the UK is illegal, to do so would constitute direct discrimination under section 13 of the Equality Act 2010. Profiling passengers solely on the grounds of ethnicity could also amount to racial harassment under section 26 of the Act, where a person feels 'humiliated, offended or degraded because of their race'. The potential consequence is that these experiences of individuals produces a negative view of policing, which can contribute to the radicalisation of individuals and entrenching social divides. ${ }^{80}$ This is particularly so when one considers the overwhelming numbers of Muslim airline passengers who have nothing to do with terrorism even though they might fit a particular 
profile. ${ }^{81}$ As previously mentioned, the 2014 Code of Practice governing Schedule 7 specifically does not allow ethnicity to be the only reason for stopping someone but, once stopped, a person can be questioned about their religious beliefs and activities within their religious communities. Once officers open this line of questioning, it is questionable whether this could be 'legitimate' under the procedural justice model. There have been many other modelling programmes to suggest that passengers could be assigned to a certain class of security check without racially profiling passengers, for example by the age of passengers or pre-approved screening passengers who could then be fast tracked at security.

Schedule 7 of the Terrorism Act 2000, could be described more accurately as a development from dealing with the 'Troubles' in Northern Ireland under the Prevention of Terrorism (Temporary Provisions) Act $1984 \& 1989$ Schedule 5 rather than a response to 9/11. Schedule 7 cannot be described as an instrument that was designed to facilitate profiling, nevertheless it can support those who believe they have profiled a suspected passenger.

To conclude this section, there appears therefore to be tension between these studies that provides evidence of feelings of discriminatory policing within the Muslim community and of racial profiling at airports compared to the view of Anderson that Schedule 7 is not being exercised in a discriminatory way. ${ }^{82}$ This study was designed to partly test whether there is evidence of racial profiling based on the experiences of the respondents in the target group.

\section{The Survey of Young Passengers' Perceptions of Security}

In the context of studies carried in the UK and negative perceptions of UK policing and use of Schedule 7 as well as passenger satisfaction surveys carried out by the CAA, the following hypotheses were tested in this study.

1. Passengers are reassured of high levels of security at UK airports ( $H_{0}$ null)

2. Airport security applies risk assessment equally to all passengers in UK airports ( $H_{0}$ null) 
3. Age is not a factor in the time it takes to go through UK airport security. ( $H_{0}$ null)

The questions specifically related to security staff professionalism when stopped (actual experience) and questions relating to respondent opinion of profiling and discrimination towards non-white ethnic passengers (their opinions). The hypotheses relate to all security staff who check passengers prior to electronic screening and post screening when the police may carry out Schedule 7 questioning. The term 'stopped' in this research includes when passengers leaving the UK have had their hand luggage or they have themselves triggered an alarm that warrants further screening, questioning and possible confiscation. It also includes when entering the UK, passport and customs checks that have warranted further search or investigation. The purpose of including these variables was to gain as much information from respondents' personal aviation security interactions and whether age had any relevance to security. This can be seen from the high level of stops (287 from 711 respondents). In addition, respondents could reflect on several flights, because often passengers have no interaction to speak of going through security but will remember the incidents they do for example when an item is confiscated. The total flight experiences recorded from 711 respondents was 3952 which suggests they had a $14 \%$ chance of a security stop. This relatively high percentage of stops is explained later when reviewing the third hypothesis of whether age impacted of the time it takes to process passengers through security. The majority of the respondents had used local airports, $64 \%$ from Manchester and Leeds Bradford airports.

The focus of this study is on a community of respondents (students) registered at Leeds Beckett University (LBU). 711 students were surveyed from 2012 to 2015 to consider their experiences and attitudes towards security at UK airports. The rationale for the data subject was that since $9 / 11$ a large number of UK university students have either carried out terrorist attacks or supported such causes. Since the destruction of the Isis Caliphate in Syria in 2019, interviews with UK Isis fighters in Kurdish camps have revealed the high number of former 
university students. ${ }^{83}$ Universities have been recognised as a source for the radicalisation of vulnerable students and have consequently been targeted in counter-terrorism measures. ${ }^{84}$ The Counter-Terrorism and Security Act 2015 (CTSA 2015) Schedule 6 imposes duties on specified authorities, such as universities to establish the 'Prevent' policy and to actively engage where students might be radicalised and drawn into terrorism. ${ }^{85}$

The sample size of 711 in this study needs to be understood in the context of total passenger numbers. In 2015, around 251 million passengers used UK airports. ${ }^{86}$ In 2030 there are expected to be more than 400 million passengers using UK airports each year. ${ }^{87}$ These statistics might suggest that the sample size to test UK airport passenger security experience should be high to ensure a high degree of reliability of this or any research into aviation security. This sample size can also be compared with the passenger satisfaction surveys carried out by the CA since 2008, The CAA use a sample size (cumulatively) of around 20,000 respondents from several airports to measure passenger experience, which includes their experience of security. In the CAA survey four questions focus on passenger security experience. ${ }^{88}$ By targeting certain airports the CAA are narrowing the total possible passenger population and allowing a lower sample size to establish viable data sample for an overall assessment. ${ }^{89}$ The CAA had categorised their respondents by age groups and had asked their respondents how long the security process had taken. The data had shown younger passenger groups do take longer to be processed than older passenger groups, particularly at Stansted Airport. Similar questions were asked in this study, but with a view of crossreferencing CAA data and establishing if this study concurred similar time process and more importantly where the CAA data was lacking, whether there could be an explanation for this. The majority of respondents in this study were aged between 18-25; actual age was not requested because of the presumption that the majority of the sample would be young. There is likely to be a higher use of regional airports such as Leeds Bradford and Manchester due to the location of LBU. The respondents had used all major UK airports..$^{90}$ The police and security personnel at airports are tasked with screening luggage as well as profiling passengers to 
consider whether they are worthy of further questioning. Suspicion is likely to result in the use of Schedule 7 TA 2000 to determine whether they are a terrorist.

Ethnicity in this project is described as white or non-white. The original categories of ethnicity consisted of three white groupings which accounted for $61.9 \%$ of total ethnicity and fourteen non-white (39.1\%), of which many groups had low numbers, for example, Chinese accounted for one respondent. Table 1 below sets out the 17 possible ethnic options respondents could select. The data set was recoded from this large list of ethnic backgrounds and divided into two categories white and non-white, to enable a Pearson Chi-Square $x^{\wedge} 2$ test. $^{91}$ 
Table 1 Ethnicity

\begin{tabular}{|c|c|c|c|}
\hline Ethnicity & Frequency & $\%$ & Cumulative \% \\
\hline White British & 417 & 58.6 & 58.6 \\
\hline White Irish & 2 & .3 & 58.9 \\
\hline Other white & 21 & 3.0 & 61.9 \\
\hline $\begin{array}{l}\text { Asian or Asian British } \\
\text { Indian }\end{array}$ & 19 & 2.7 & 64.6 \\
\hline $\begin{array}{l}\text { Asian or Asian British } \\
\text { Pakistani }\end{array}$ & 127 & 17.9 & 82.4 \\
\hline $\begin{array}{l}\text { Asian or Asian British } \\
\text { Bangladeshi }\end{array}$ & 11 & 1.5 & 84.0 \\
\hline Chinese & 1 & .1 & 84.1 \\
\hline Other Asian & 18 & 2.5 & 86.6 \\
\hline $\begin{array}{l}\text { Black or Black British } \\
\text { Caribbean }\end{array}$ & 10 & 1.4 & 88.0 \\
\hline $\begin{array}{l}\text { Black or Black British } \\
\text { African }\end{array}$ & 44 & 6.2 & 94.2 \\
\hline Other Black & 6 & .8 & 95.1 \\
\hline $\begin{array}{l}\text { Mixed White and Black } \\
\text { Caribbean }\end{array}$ & 12 & 1.7 & 96.8 \\
\hline $\begin{array}{l}\text { Mixed White and Black } \\
\text { African }\end{array}$ & 5 & .7 & 97.5 \\
\hline Mixed White and Asian & 5 & .7 & 98.2 \\
\hline Other mixed & 6 & .8 & 99.0 \\
\hline Other ethnicity & 5 & .7 & 99.7 \\
\hline No response & 2 & .3 & 100.0 \\
\hline Total & 711 & 100.0 & \\
\hline
\end{tabular}


White includes British, Irish and other which cumulatively accounts for $61.9 \%$ of all respondents. The ethnicity in the LBU Law School during the four years of this sample for non-whites i.e. all categorised other white in Table 1 averaged at $39.75 \%$. Further analysis of profiling questions used cross-tabulation analysis to enable more variables to be assessed such as sex, and further recoding of ethnicity into wider-ranging groupings. The recoded ethnic groups for the cross-tabulation analysis were white, South Asian, black and other (see Tables 3-6). The largest non-white ethnicity group was Asian or Asian British Pakistani which accounted for 127 respondents or $17.9 \%$. No religious data was gathered but an assumption can be made that this category would contain many Muslim respondents. The ethnicity of this data sample was measured against the university monitoring data over the four years of the survey and confirmed that the ethnicity and sex in the survey was representative of the university population during this time.

\section{Questions and Findings}

The following presentation of findings concerns the hypothesis 2, i.e. airport security applies risk assessment equally to all passengers in UK airports $\left(H_{0}\right.$ null). In this series of questions relating to profiling passengers, respondents were required to indicate whether they agree or disagree with the statement made. Respondents were asked whether they agreed or disagreed that profiling gives an opportunity for security to harass ethnic minorities. Table 2 shows the overwhelming majority of respondents (605 or $85 \%$ ) disagree that profiling gives an opportunity to harass ethnic minorities, differences in proportions of white and non-white who disagree are observed.

Table 2: Do you agree or disagree that profiling gives an opportunity for security to harass ethnic minorities?

\begin{tabular}{|ll|r|r|r|}
\hline & \multicolumn{2}{|c|}{$\begin{array}{c}\text { Profiling gives an } \\
\text { opportunity for security to } \\
\text { harass ethnic minorities }\end{array}$} & \multicolumn{2}{|c|}{ Total } \\
\cline { 3 - 4 } & Disagree & Agree & \\
\hline White and Non-white & White & 410 & 30 & 440 \\
categories & Non- & 195 & 74 & 269 \\
\hline
\end{tabular}


A Chi-square test was carried out to see if these differences were significant. The expected count in all cells was five or more so the test is valid. Therefore, the $H_{0}$ from this example could be rejected and consequently, risk assessment does not apply equally to all passengers in the opinion of these respondents.

Respondents were asked whether they agreed or disagreed whether airport security legitimises discrimination against ethnic minorities. Table 3 shows the overwhelming majority of respondents (676 or $95 \%$ ) disagree that airport security legitimises discrimination against ethnic minorities, however differences in the proportion of white and non-white who disagree are observed.

Table 3: Do you agree or disagree that Airport security legitimises discrimination against ethnic minorities?

\begin{tabular}{|ll|r|r|r|}
\hline & & \multicolumn{2}{|c|}{$\begin{array}{c}\text { Airport security legitimises } \\
\text { discrimination against } \\
\text { ethnic minorities }\end{array}$} & \multicolumn{2}{|c|}{ Total } \\
\cline { 3 - 4 } & \multicolumn{1}{|c|}{ Disagree } & \multicolumn{1}{|c|}{ Agree } & \\
\hline White and Non-white & White & 428 & 12 & 440 \\
categories & Non- & 248 & 21 & 269 \\
Total & white & 676 & 33 & 709 \\
\hline
\end{tabular}

A Chi-square test was carried out to see if these differences were significant. The expected count in all cells was five or more so the test is valid. Therefore, from this example the $H_{0}$ would be rejected and risk assessment does not apply equally to all passengers in the opinion of these respondents.

The Chi-square test in both of the above examples shows a minority of respondents did agree that airport security discriminates and is an opportunity to harass minorities. There is a significant difference from white and non-white respondents relating to their perceptions of airport security rather than their actual experiences. Although from this data ethnic minorities 
might assume that if stopped, the reason is related to their ethnicity rather than anything else. Legitimacy of stopping passengers remains important for these reasons, particularly the professionalism of security in rationalising the stop.

A number of provocative question were asked of the respondents to try to test whether profiling terrorists is realistic on the basis of observation alone. For example, it is obvious who terrorists are simply by their appearance. Table 4 shows overwhelming disagreement from both male $75.2 \%(200)$ and female $81.9 \%$ (363) respondents with the idea that it is obvious who terrorists are simply by their appearance.

Table 4: Do you agree or disagree that profiling is a good idea because it is obvious who the terrorists are?

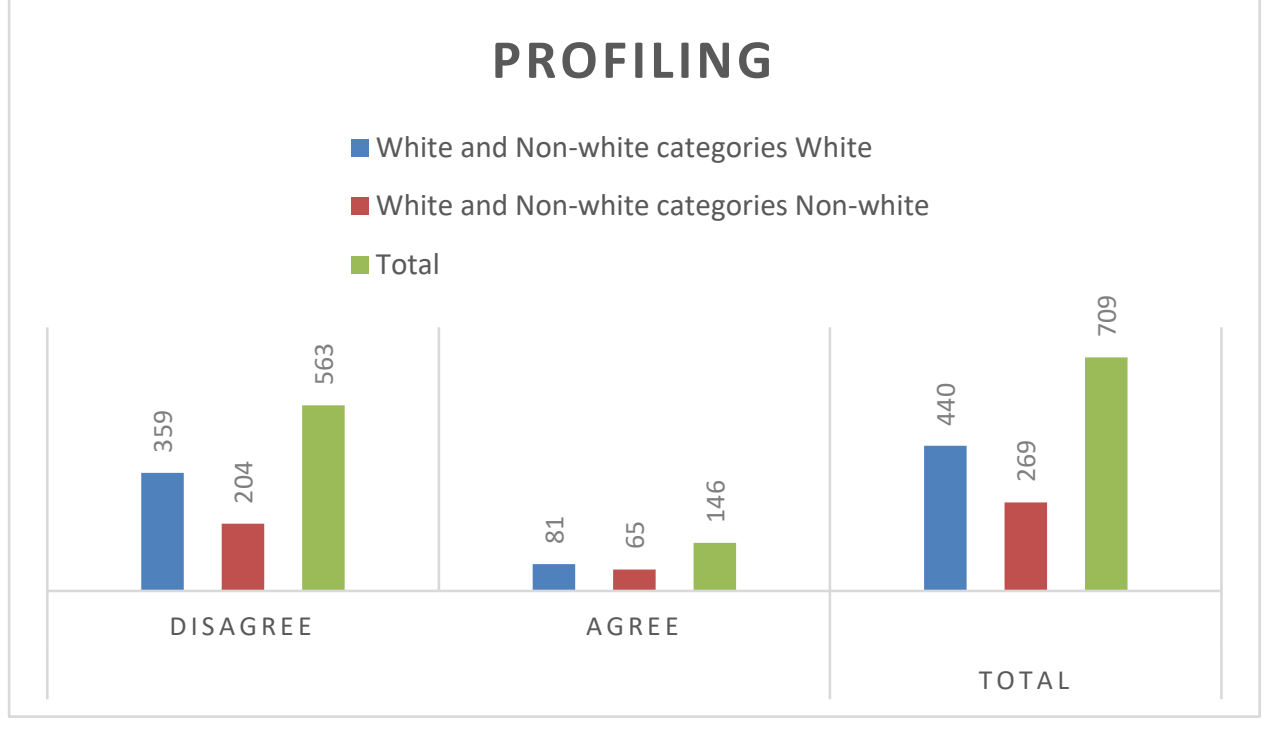

The number of male and female respondents who agree with the statement, although low, are relevant. This is evidence of potential discriminatory attitudes amongst the respondents. It is impossible to specifically determine whether someone is a terrorist from observation only, unless they are in the process of carrying out a terrorist attack or found to be carrying weapons and explosive. Of those respondents who suggested that terrorists can be identified by observation 80 were female, and $65 \%$ were white British. However, of the 66 male respondents only $43.9 \%$ were white British suggesting an ethnic and gender difference in attitudes towards observation. However, a greater proportion of men (33\%) than women (22\%) supported the statement that profiling is a good idea because it is obvious who the 
terrorists are. It is interesting from this data that more male non-white ethnic respondents believe they can determine terrorist by observation alone.

The majority of females (82.4\%) and males (64.3\%) agree that profiling gives an opportunity to target passengers acting suspiciously. Table 5 shows those respondents who disagree with this question a higher proportion were male Asian, black and other. There is also a difference in gender opinions for respondents who disagree with the question with $35.7 \%$ male and $17.6 \%$ female. This data could suggest ethnic males view profiling in general more suspiciously than females.

Table 5: Do you agree or disagree that profiling gives an opportunity to target those acting suspiciously?

\section{PROFILING}

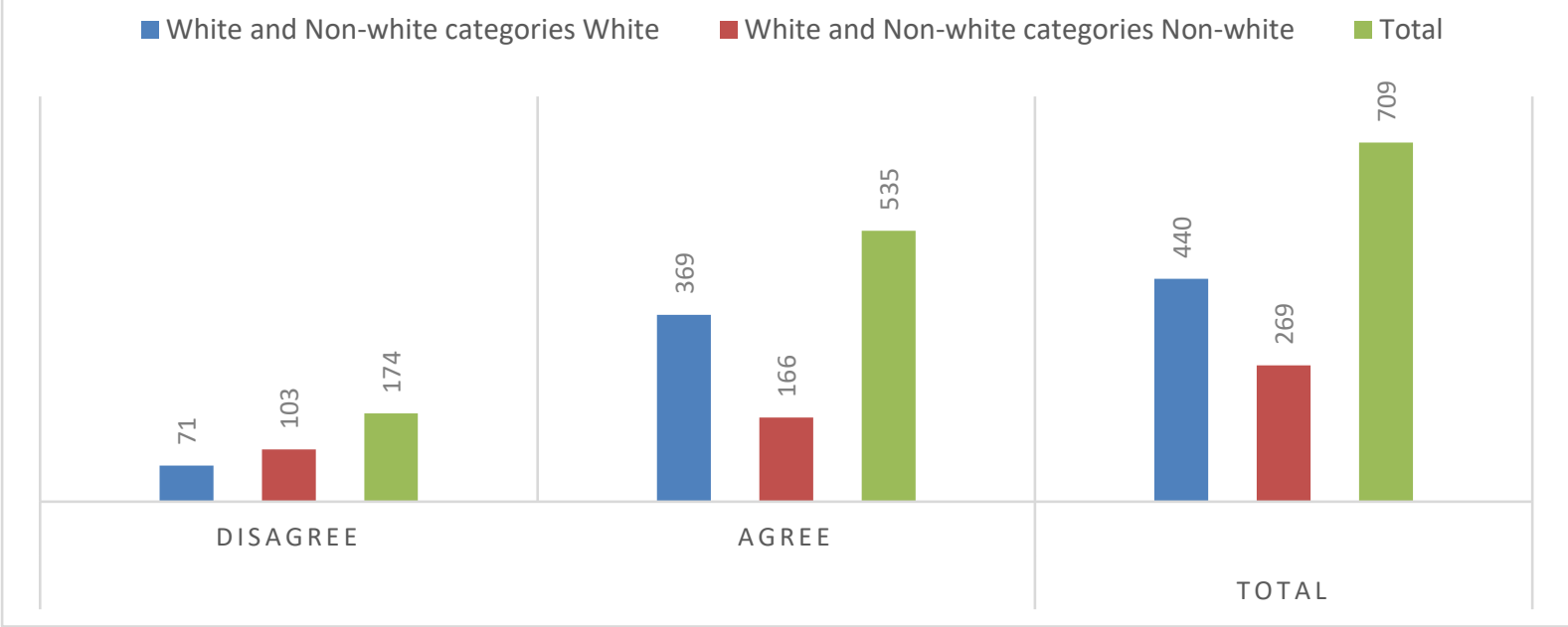

Table 6 shows there is an overwhelming disagreement with the idea that ethnic minorities should be subject to higher security checks with 709 respondents suggesting that all passengers should be profiled in the same manner.

Table 6: Do you Agree or Disagree that ethnic minorities should be subject to higher levels of security checks? 


\section{RESPONDENT OPINION}

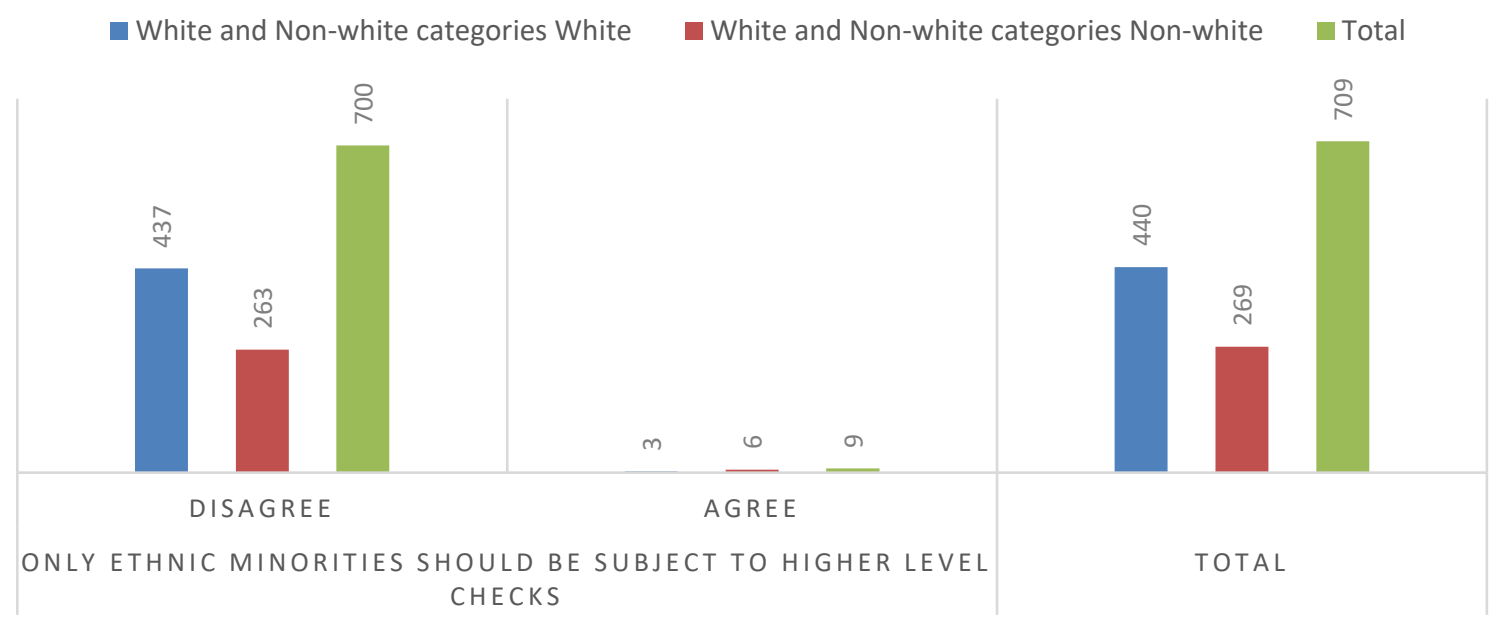

It could be suggested that this data shows that ethnicity should never be a reason to suspect someone of either being involved with a crime or terrorism. However, there must always be an opportunity for security staff to question passengers who are acting suspiciously.

\section{Measuring perception with experience}

A minority of non-white respondents in this study perceived that some elements of security process was discriminatory to ethnic minorities and could be interpreted as evidence for racial profiling. However, this should be seen in the context that others parts of this study identified that respondents were generally stopped because they had triggered electronic screening resulting in 187 confiscated items. Table 7 outlines those items

\section{Table 7: What was the Item Confiscated?}




\section{WHAT WAS THE ITEM CONFISCATED}

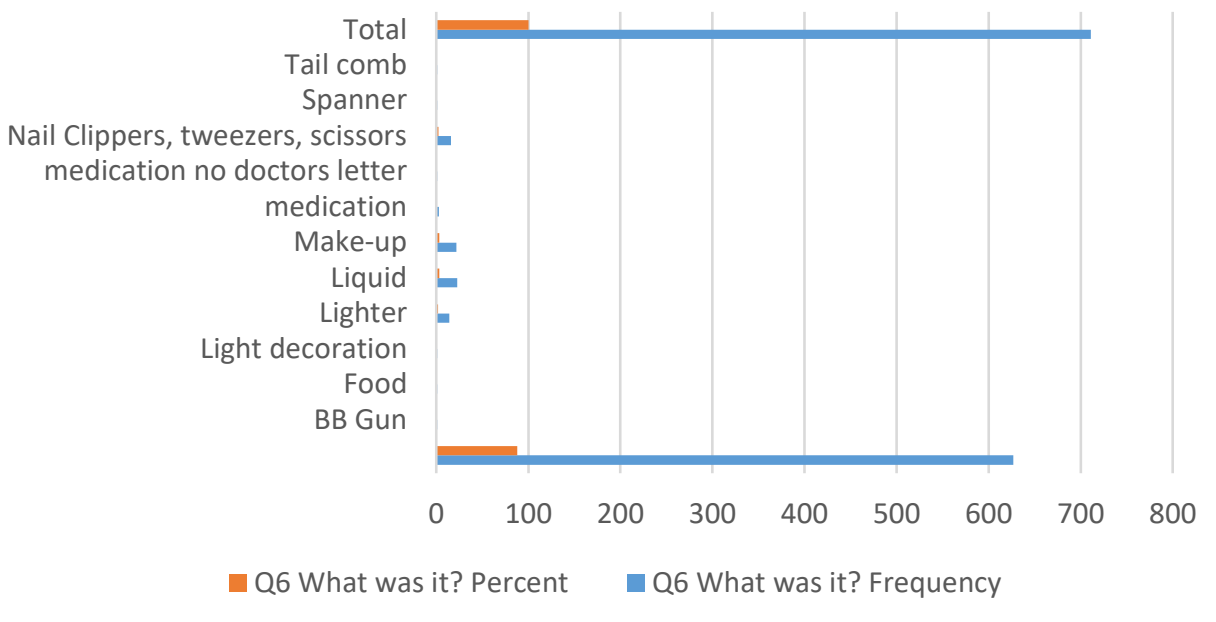

This study also established that that younger passengers take longer to proceed through security and this confirms CAA data measuring the time it takes passengers, by age group, to proceed through UK airport security. The CAA data has no explanation why this might be. This study suggests that delay in security processes may be due to the fact that younger passengers pay less attention to prohibited items consequently increasing the interactions with security who are required to search hand luggage and ask further questions if something has been detected. These passenger interactions with security personnel could increase the perception of a lack of legitimacy in cases where passengers fail to comply with security rules, for example liquids in one clear plastic bag that do not exceed $100 \mathrm{ml}$. This is an alternative account to the proposition that lack of legitimacy of the security process is due to a perception of racial profiling of ethnic minorities.

The airport security process concerning embarkation has become increasingly lengthy and intrusive. Its legitimacy is established by the public perception that this process embodies procedural justice. Airports face competing pressures to be commercially viable on the one hand and fulfil a duty of care to passenger safety and ensure compliance with regulatory requirements. On the other hand, a key question is what is the evidence that the current security process is fit for purpose and indeed should there be a radical re-think as to the 
effectiveness of screening processes at airports. Linos et al have questioned whether the existing process at airports would pass the National Screening Committee's criteria for an effective screening test. ${ }^{92}$ Initiated in the National Health Service in the 1990s, the National Screening Committee has a "remit is to assess screening technologies on the basis of sound scientific evidence and advise on whether they should be implemented, continued, or withdrawn." ${ }^{\text {93 }}$ Further, Linos et al suggest that an analogous approach should be adopted to current airport security screening as " the first step to building a future airport security programme that is more user friendly and cost effective, and that ultimately protects passengers from realistic threats". ${ }^{94}$

\section{Concluding Discussion and Suggested Reforms}

Does the data produced in this study corroborate or challenge other research findings around the existence of racial profiling in UK policing at airports? In all of the survey questions and open comments, respondents were positive about security and appeared to implicitly be supporting the legitimacy of this approach of re-assurance policing based on procedural justice. Respondents overwhelmingly rejected questions that suggested ethnic minorities should be treated differently to white passengers. Indeed, as mentioned in the data analysis of this hypothesis, for the question, 'only ethnic minorities should be subject to higher level checks' (see Table 6), only three respondents agreed with this statement and 700 disagreed. Nevertheless, other questions that were asked relating to profiling showed that whilst there was support for the existing security measures at UK airports, there was a significant difference of opinion between white and non-white respondents. Although the overwhelming majority of respondents in the study who had been stopped ( 287 or $92 \%$ ) agree that they were dealt with professionally, differences in proportions of white and non-white who disagree are observed. The perception of airport security is important particularly when security staff are reliant upon passengers to be both corporative and willing to report suspicious behaviour. This study confirms the findings of other research detailed above insofar that in a minority of non-white passengers have concerns in the way they are treated at airports in the UK. This 
perception of profiling cannot be interpreted as providing evidence of a practice of racial profiling however.

This study revealed that young passengers are more likely to have an impact on the time it takes to process them through security due to what appeared to be a casual approach to prohibited items allowed in the aircraft cabin. Therefore to save time processing passenger through security one aspect of profiling should be concentrated on young passengers before entering the security zones. This study also confirms the findings of other social science research that non-white passengers have concerns about the way they are treated at airports in the UK. However, the public consciousness, particularly on non-white passengers as Welch suggests, ${ }^{95}$ may influence their perceptions about their racial identity through media reporting about crime or terrorist attacks which leads them to conclude when they have been stopped or items confiscated due to their racial identity. However, it cannot be overstated that overall the respondents, including those from ethnic minority backgrounds, are supportive of high levels of security. Nevertheless, there are a number of practical measures such as monitoring passenger satisfaction and by providing quick routes of feedback by passengers of their experience to ensure those carrying out any screening can respond quickly and professionally. The data suggests that further training of security officials and the police embedding procedural justice could alleviate non-white passenger concerns about their perceived ideas of police selecting passengers on the grounds of their ethnicity.

It is very unlikely that when passengers are initially stopped they will be informed that the authority to stop and question them is under Schedule 7, its purpose to determine whether they are a terrorist. Indeed, to do so could cause alarm. In most cases, passengers are allowed to go on their way. Schedule 7 remains a powerful tool to stop, search and detain passengers, without any need for reasonable suspicion but with a view to determining whether they are terrorists. Tensions within the Muslim communities who feel that they are treated differently and as being 'other', are likely to continue, exacerbated by new legal developments designed to strengthen detection and prevention of British Nationals going to fight abroad in places such 
as Syria. The introduction of measures in the Counter-Terrorism and Security Act 2015, it is argued is likely to have focused disproportionally on Muslim passengers at airports. ${ }^{96}$

The public review of Schedule 7 in 2012 was a lost opportunity to impose robust safeguards for persons detained 15 minutes or more, which would strike a balance between flexibility and requiring officers to have reasonable suspicion to detain persons for longer than 15 minutes. ${ }^{97}$ Data suggests that most passengers travelling are detained for no more than a few minutes. ${ }^{98}$ There appears to be some logic and a need for a flexible approach to stop passengers and all passengers that are stopped are subject to a number of standard checks. Schedule 7 can thus be justified as a necessary and proportionate safeguard. Examining officers who cannot articulate to passengers why they are being detained for fifteen minutes or more should forfeit any right to detain passengers. Additionally, it is difficult to understand at this point why any further detention would be necessary without reasonable suspicion. Striking a balance between security and civil liberties against a backdrop of actual and attempted aviation attacks is about effective risk assessment and sensitive practices. ${ }^{99}$ However, identifying particular profile indicators for examination, such as flight routes need to be balanced with the fact that the overwhelming majority of passengers do not pose any risk to aviation security. It is clear from the 2017 UK terrorist events and the introduction of the Counter-Terrorism and Border Security Act 2019 that the UK is determined to continue to broaden its powers against terrorists and hostile acts and strengthen its borders. 


\footnotetext{
${ }^{1}$ Martin Innes, "The Reassurance Function, Policing", Oxford Journals (2007) 132-140

2 Jason Sunshine and Tom R. Tyler, "The Role of Procedural Justice and Legitimacy in Shaping Public Support for Policing" [2003] Law and Society Review, vol 37 no3, 513-547. Also see Martin Innes "Signal crimes and signal disorders: notes on deviance as communicative action", [2004] The British Journal of Sociology vol 55

${ }^{3}$ BBC News 'Brussels explosions: What we know about airport and metro attacks' Accessed March 252016 http://www.bbc.co.uk/news/world-europe-35869985.

4 Innes, "The Reassurance Function, Policing" (see note1)

${ }^{5}$ Kathleen M Sweet 'Aviation and Security Terrorism and Safety Concerns' (Pearson Education 2004) 18

${ }^{6}$ Susan Trento, and Joseph Trento, Unsafe at Any Altitude: Failed Terrorism Investigations, Scapegoating 9/11, and the Shocking Truth About Aviation Security Today. (Hanover, N.H: Steerforth Press 2006)

${ }^{7}$ Donna Smith 'Passenger Profiling: A Greater Terror Than Terrorism Itself'; Marshall L. Rev. (1999):167.

${ }^{8}$ Home Office 'Examining Officers and Review Officers under Schedule 7 of the Terrorism Act 2000' July 2014. Accessed May 022016 https://www.gov.uk/government/uploads/system/uploads/attachment_data/file/339197/schedule7.pdf See also Peter B. Ainsworth 'Offender Profiling and Crime Analysis' (Routledge 2011) 7-18.

9 ibid

${ }^{10}$ The 9/11 nineteen male Muslim hijackers were mostly 25 years old and below, Umar Farouk Abdulmutallab popularly referred to as the "Underwear Bomber" was aged 23.,
} 
${ }^{11}$ Tufyal Choudhury and Helen Fenwick, The impact of counter-terrorism measures on Muslim communities (Equality and Human Rights Commission Research 2011 report) 72.

12 Shaun L. Gabbido, Everette B. Penn,Kareem L. Jordan, and George E. Higgins 'The Influence of Race/Ethnicity on the Perceived Prevalence and Support for Racial Profiling at Airports' Criminal Justice Policy Review vol 20 no 3 September (2009): 346.

${ }^{13}$ Chrystie Flournoy Swiney "Racial Profiling of Arabs and Muslims in the US: Historical, Empirical, and Legal Analysis Applied to the War on Terroris". Muslim World Journal of Human Rights vol 3, iss 1, (2006): Article 3.

${ }^{14}$ Gabe Mythen, Sandra, Walklate, and Fatima Khan, (2009) "I'm a Muslim, but I'm not a Terrorist": Victimization, Risky Identities and Performance of Safety The British Journal of Criminology Vol 49 Iss $6,736-754$

15 ibid

${ }^{16}$ Yevgenia S Kleiner 'Racial Profiling in the name of national security: Protecting minority travellers' civil liberties in the age of terrorism' 30 B. C Third World Law Journal, (2010): 103-144.

17 Schedule 7 TA 20001 (1)

18 Schedule 7 TA 20006 (4)

19 Schedule 7 TA 11. (2) (a)

20 Schedule 7 TA 20002 (4)

${ }^{21}$ David Miranda v SSHD [2016] EWCA Civ 6 para 58

22 Schedule 7 TA 200018 (1)

23 Schedule 7 TA 200016 (1)

${ }^{24}$ Schedule 8 TA (2) 1

25 The Code of Practice for Examining Officers under the Schedule 7 Terrorism Act 2000 Accessed August 032016 http://www.legislation.gov.uk/ukdsi/2009/9780111474587.

${ }^{26}$ Schedule 7 Code of Practice Accessed July 12, 2015.

https://www.gov.uk/government/consultations/schedule-7-code-of-practice.

27 The Report of the Independent Reviewer on the Operation of the Terrorism Act 2000 and Part 1 of The Terrorism Act 2006 pursuant to s36 of the Terrorism Act 2000 July (2012), 99.

28 David Anderson Q.C. Report on the Operation in 2010 of the Terrorism Act 2000 and of Part 1 of the Terrorism Act 2006. July 2011.

${ }^{29}$ Review of the Operation of Schedule 7 A Public Consultation 4. Accessed October 13, 2016.

https://www.gov.uk/government/uploads/system/uploads/attachment data/file/157896/consultationdocument.pdf.

${ }^{30}$ Examining Officers and Review Officers under Schedule 7 of the Terrorism Act 2000 Code of Practice July 2014 Accessed May 01, 2017. https://www.gov.uk/government/consultations/schedule7-code-of-practice.

${ }^{31}$ David Anderson Report on the Operation in 2014 of the Terrorism Act 2000 and Part 1 of the Terrorism Act 2006, September 2015, 28, Accessed October 12, 2017.

https://terrorismlegislationreviewer.independent.gov.uk/wp-content/uploads/2014/07/Independent-

Review-of-Terrorism-Report-2014-print2.pdf

32 lbid 7 
${ }^{33}$ David Anderson Report on the Operation in 2014 of the Terrorism Act 2000 and Part 1 of the Terrorism Act 2006, September 2015, 24, Accessed October 12, 2017.

https://terrorismlegislationreviewer.independent.gov.uk/wp-content/uploads/2014/07/Independent-

Review-of-Terrorism-Report-2014-print2.pdf

${ }^{34}$ David Miranda v SSHD [2016] Civ 6 para 118-119

${ }^{35}$ Nicholas Watt, 'David Miranda: Lib Dems back motion criticising anti-terrorism powers' The Guardian 18 Sep 2013 Accessed 20 February 2018

https://www.theguardian.com/politics/2013/sep/18/david-miranda-lib-dems-anti-terrorism-powers

${ }^{36}$ Anti-social Behaviour, Crime and Policing Act 2014

${ }^{37}$ The Code of Practice for Examining Officers under the Schedule 7 Terrorism Act 2000 4-7

Accessed August 2016 http://www.legislation.gov.uk/ukdsi/2009/9780111474587.

${ }^{38}$ Constables, Immigration, or custom officers 1A (1) (a).

39 David Lowe 'Terrorism law and Policy' (Routledge 2018) 79

${ }^{40}$ Martin Innes, Reinventing Tradition' reassurance, neighbourhood security and policing',[2004]

Criminal Justice, Sage Publications

${ }^{41}$ Kenneth Oxford 'Policing by Consent' in Essays Reflecting on Lord Scarman's Report, the Riots and their Aftermath 1984, 114-124 Published by Elsevier Ltd Accessed November 12, 2018.

https://www.sciencedirect.com/science/article/pii/B9780080302171500174 See Jonathan Jackson, Mike Hough, Ben Bradford, Katrin Hohl and Jouni Kuha Policing by Consent: UK evidence on legitimate power and influence European Social Study Topline Results (UK) Accessed 18 October 2018 https://s3.amazonaws.com/academia.edu.documents/45644579/ess-uk-findings-wordversion.pdf?AWSAccessKeyld=AKIAIWOWYYGZ2Y53UL3A\&Expires $=1542363075 \&$ Signature=\%2Fk cOqhZkYovtdfmQ3i8WzdFfIYY\%3D\&response-content-

disposition=inline\%3B\%20filename\%3DPolicing by consent.pdf

${ }^{42}$ Home Office 92012)Definition of policing by consent

https://www.gov.uk/government/publications/policing-by-consent/definition-of-policing-by-consent

43 Innes, "The Reassurance Function, Policing" (see note 1).

44 Ibid, 136.

${ }^{45}$ Adam Stone 'Air marshals have to be smart, fit and good shooters' Military Times (2015)

Accessed June 13, 2016. http://www.militarytimes.com/story/veterans/careers/civilian/2015/04/27/airmarshals-have-to-be-smart-fit-and-good-shooters/24838437/.

46 Jelmer Brouwer, Maartje Van Der Woude and Joanne Van Der Leun, "Border policing, procedural justice and belonging: the legitimacy of (cr)immigration controls in border areas", British Journal of Criminology 58, no. 4 (2017): 624-643, 626: also see Tom Tyler, "Procedural Fairness and Compliance with the Law"', Swiss Journal of Economics and Statistics 133, (1997): 219-240.

47 Jonathan Simon 'Governing through Crime', (Oxford: Oxford University Press 2007).

${ }^{48}$ Paddy Hillyard, 'The "War on Terror": Lessons from Ireland' (2005), in European Civil Liberties Network, Essays for Civil Liberties and Democracy in Europe. Available at:

$<$ http://www.ecln.org/essays/essay-1.pdf> accessed 23 May 2014.

${ }^{49}$ Paddy Hillyard, 'Suspect Community: People's Experiences of the Prevention of Terrorism Acts in Britain', (London Pluto Press 1993)

50 Yevgenia S. Kleiner 'Racial Profiling in the name of National Security: Protecting minority travellers civil liberties in the age of terrorism' (Third World , L J. 2010) 103

$<$ http://lawdigitalcommons.bc.edu/twlj/vol30/iss $1 / 5>$ accessed 12 July 2014

${ }^{51}$ Neil Chakraborti in Rowe M. 'Policing Muslim Communities', Policing beyond Macpherson: Issues in Policing, Race and Ethnicity 2007(CullomptonWillan 2007)

52 Tufyal Choudhury and Helen Fenwick (2011) 'The impact of counter-terrorism measures on Muslim communities' (Equality and Human Rights Commission Research 2011 report) 
${ }^{53}$ Christina Pantazis and Simon Pemberton 'From the 'Old' to the 'New' Suspect Community Examining the Impacts of Recent UK Counter-Terrorist Legislation' In the Br J Criminology [2009] 49 (5): 646-666.

${ }^{54}$ Karen, Hurrell 'An Experimental Analysis of Examinations and Detentions under Schedule 7 of the Terrorism Act 2000' (Equality and Human Rights Commission 2014) Briefing Paper 8

${ }^{55}$ Ibid. p 7.

${ }^{56}$ National Police Chief Council freedom of Information request 000136/16 Accessed December 12, 2018 https://www.npcc.police.uk/FOl\%202016/CT/136\%2016\%20Schedule\%207.pdf

${ }^{57}$ Brandon R. Langley 'A randomised control trial comparing the effects of procedural justice to experienced utility theories in airport' (MSc Cambridge University 2014) 3, 16-33.

${ }^{58}$ Kahneman, D. and Tversky, A. (2000) Choices, Values and Frames, Cambridge: Cambridge University Press.

${ }^{59}$ Choudhury and Fenwick 'The impact of counter-terrorism measures on Muslim communities' (see note 14).

${ }^{60}$ Leda Blackwell, Nick Hopkins and Steve Reicher, "I know who I am, who do they think I am?:

Muslim perspectives on encounters with airport authorities." Ethnic and Racial Studies 36(6) (2013a): 1090 - 1108. Also see Darren Thiel, 'Policing Terrorism 'A Review of the Evidence': (The Police Foundation London 2009)

61 Badi Haisi and David Weisburd, "Going Beyond Ascribed Identities: the Importance of Procedural Justice in Airport Security Screening in Israel", Law and Society Review 45, (2011).

${ }^{62}$ Gali Perry \& Badi Hasisi (2018) Closing the Gap: Promoting Suspect Communities' Cooperation with Airport Security, Terrorism and Political Violence, DOI: 10.1080/09546553.2018.1442331

63 ibid

${ }^{64}$ Government Accountability Office 'TSA's Passenger Screening Behaviour Detection Program Underway, but Opportunities Exist to Strengthen Validation and Address Operational Challenges' May $2010<$ http://www.gao.gov/assets/310/304510.pdf> (accessed 10 February 2013) .

65 ibid

${ }^{66}$ Department of Homeland Security, 'Office of Inspector General Transportation Security Administration's Screening of Passengers by Observation Techniques'. May 2013.

$<$ https://www.oig.dhs.gov/assets/Mgmt/2013/OIG 13-91 May13.pdf> (accessed 14 July 2014)

67 ibid 5

68 ibid

${ }^{69}$ Government Accountability Office TSA Should Limit Future Funding for Behaviour Detection Activities November 2013 <http://www.gao.gov/assets/660/658923.pdf> (accessed 30 January 2014) 70 Department of Homeland Security, 'Office of Inspector General Transportation Security Administration's Screening of Passengers by Observation Techniques'. May 2013. $<$ https://www.oig.dhs.gov/assets/Mgmt/2013/OIG_13-91_May13.pdf> (accessed 14 July 2014) ${ }^{71}$ Ben Bowling, Alpa Parmar \& Coretta Phillips 'Policing ethnic minority communities Ben Bowling, Alpa Parmar \& Coretta Phillips' ch 21 in Policing ethnic minority communities Ben Bowling and Coretta Phillips Policing ethnic minority communities (LSE online 2010). Accessed September 2017 http://eprints.Ise.ac.uk/9576/1/Policing ethnic minority communities (LSERO).pdf. 
72 James Whitfield 'The historical context: policing and black people in post-war Britain In 'Policing beyond Macpherson ed Rowe, M. (Willan Publishing 2007) 1-16. See K. Sheik Pal, Racial Profiling as a Pre-emptive Security measure after September 11: A suggested Framework for Analysis, Kennedy School Review, (2018) 199-220.

${ }^{73}$ Melissa Hickman Barlow Race and the problem of crime in Time and Network cover stories, 1946 to 1995 Social Justice,(1998) 25,149-183 and Hawkins ,D, F Ethnicity, race, and crime New York Press 1995)11-45 both in Kelly Welch'(2007) ‘Black Criminal Stereotypes and Racial Profiling' Journal of Contemporary Criminal Justice Vol 23 No 3 pp276-288 Sage Publishing.

${ }^{74}$ There are a number of academic viewpoints on this matter that suggest a relationship between the Catholic communities in the 'Troubles' have a bearing on the similar experiences as the Muslim community today, as well as policing ethnic communities in general. The following are a sample, Christina Pantazis and Simon Pemberton 'From the 'Old' to the 'New' Suspect Community Examining the Impacts of Recent UK Counter-Terrorist Legislation' In the Br J Criminology 49, 5: (2009): 646666. See Equality Commission for Northern Ireland Statement on Key Inequalities in Northern Ireland. Belfast: (2007) ECNI. Paddy Hillyard, 'The "War on Terror": Lessons from Ireland' in (European Civil Liberties Network 2005), Essays for Civil Liberties and Democracy in Europe. Available at: <http://www.ecln.org/essays/essay-1.pdf> (accessed 23 May 2014). See also Mark McGovern 'Countering Terror or Counter Productive? 'Comparing Irish and British Muslim Experiences of Counter-Insurgency’ Law and Policy. (Ormskirk: Edge Hill University 2010). Available at: http://www.edgehill.ac.uk/documents/news/CounteringTerror.pdf. Paddy Hillyard, 'Suspect Community: People's Experiences of the Prevention of Terrorism Acts in Britain', (London Pluto Press 1993). Neil Chakraborti in Rowe M. 'Policing Muslim Communities', in Policing beyond Macpherson: Issues in Policing, Race and Ethnicity (CullomptonWillan 2007).

75 Simon Holdaway \& Megan O'Neill, "Institutional Racism after Macpherson: An Analysis of Police Views" Policing and Society 16 (4) (2006)

${ }^{76}$ Sir William Macpherson, The Stephen Lawrence Inquiry, Cm 4262-I (London: Stationary Office, 1999).

${ }^{77}$ David Canter (2000) 'Offender profiling and criminal differentiation', Legal and Criminological Psychology 5, 23-46.

${ }^{78}$ Kelly Welch'(2007) ‘Black Criminal Stereotypes and Racial Profiling' Journal of Contemporary Criminal Justice Vol 23 No 3 pp276-288 Sage Publishing

${ }^{79}$ Melissa Hickman Barlow (1998) Race and the problem of crime in Time and Network cover stories, 1946 to 1995 Social Justice, 25,149-183.

80 H.M Government, Prevent Strategy, June 2011, para 5.26-5-30.

$<$ https://www.gov.uk/government/uploads/.../prevent-strategy-review.pdf> (accessed 20 December 2013)

${ }^{81}$ Laura A. McLay, Adrian J. Lee, Sheldon H. Jacobson, "Risk-Based Policies for Airport Security Checkpoint Screening" Transportation Science vol 44, iss 3, (2010): 333-349.

82 David Anderson Report on the Operation in 2014 of the Terrorism Act 2000 and Part 1 of the Terrorism Act 2006, September 2015, 28, Accessed October 12, 2017. 
https://terrorismlegislationreviewer.independent.gov.uk/wp-content/uploads/2014/07/Independent-

Review-of-Terrorism-Report-2014-print2.pdf

${ }^{83}$ BBC News 'At least seven from my university joined IS, says captured fighter' $1^{\text {st }}$ April 2019 https://www.bbc.co.uk/news/uk-47772772 accessed 10 April 2019

${ }^{84}$ Katherine E Brown and Tania Saeed' Radicalization and counter-radicalization at British universities: Muslim encounters and alternatives Ethnic and Racial Studies, vol 38 no 11 (2015): 1952-1968

${ }^{85}$ Counter-Terrorism and Security Act 2015 Part 5 s 26. (1) A specified authority must, in the exercise of its functions, have due regard to the need to prevent people from being drawn into terrorism.

${ }^{86}$ CAA statistical data Accessed January 21,2016.

https://www.caa.co.uk/uploadedFiles/CAA/Content/Standard_Content/Data_and_analysis/Datasets/Ai rport_stats/Airport_data_2015/Table_01_Size_of_UK_Airports_2015_Comp_2010.pdf.

87 UK Aviation Forecasts January 2013, Department of Transport Accessed May 01 2017 5-7

https://www.gov.uk/government/uploads/system/uploads/attachment data/file/223839/aviationforecasts.pdf.

${ }^{88}$ Civil Aviation Authority 'Passenger' Experiences of Air Travel' Eighth Report of Session 2006-07 vol 1. June 21st 2012 Accessed June 27, 2016. http://www.dft.gov.uk/statistics/releases/air-passengerexperience-of-security-screening-results-caa-survey-module-2011.

89 ibid

90 London Heathrow, Gatwick, Stanstead, Luton and Manchester as well as Birmingham. The respondents used several smaller airports as well.

${ }^{91}$ Standard statistics textbooks recommended the use of chi-square with $2 \times 2$ contingency tables only when the expected frequency of each cell is at least 5.

${ }^{92}$ Eleni Linos, Elizabeth Linos \& Graham Colditz 'Screening programme evaluation applied to airport security' (BMJ 2007) 335 (7633) 1290-1292

${ }^{93}$ Ibid. 1291

${ }^{94}$ Ibid. 1292

${ }^{95}$ Kelly Welch'(2007) 'Black Criminal Stereotypes and Racial Profiling' Journal of Contemporary

Criminal Justice Vol 23 No 3 pp276-288 Sage Publishing

${ }^{96}$ BBC News 'Hundreds of Britons fighting in Syria - MI5 chief' 7 November 2013

<http://www.bbc.co.uk/news/world-middle-east-24856553> (accessed 18 September 2014).

${ }^{97}$ Steve Wood "The Terrorism Act 2000 Schedule 7 and its Implications for the Human Rights of

Passengers Travelling through United Kingdom Airports" Global Security Studies, (2015), vol 6, iss 1.

${ }_{98}$ David Anderson Report on the Operation in 2013 of the Terrorism Act 2000 and Part 1 of the

Terrorism Act 2006, July 2014, 42 <https://terrorismlegislationreviewer.independent.gov.uk/wpcontent/uploads/2014/07/Independent-Review-of-Terrorism-Report-2014-print2.pdf> (accessed 12 February).

${ }_{99}$ Tuomas Ojanen, Terrorist profiling; human rights concerns, Critical Studies on Terrorism, 3(2) 2010 295-312. 